\title{
Stromal cell-derived factor 1 protects human periodontal ligament stem cells against hydrogen peroxide-induced apoptosis
}

\author{
YIMIAO FENG ${ }^{1}$, XIAOHUI FU ${ }^{1}$, XINTIAN LOU ${ }^{2}$ and BAIPING FU ${ }^{3}$ \\ ${ }^{1}$ Department of Orthodontics, Second Affiliated Hospital, College of Medicine, Zhejiang University, Hangzhou, \\ Zhejiang 310009; ${ }^{2}$ Department of Dentistry, Punan Hospital of Pudong, Shanghai 200125; ${ }^{3}$ Department of Prosthodontics, \\ Affiliated Dental Hospital, Zhejiang University School of Medicine, Hangzhou, Zhejiang 310000, P.R. China
}

Received April 30, 2016; Accepted March 23, 2017

DOI: $10.3892 / \mathrm{mmr} .2017 .7192$

\begin{abstract}
Periodontal ligament stem cells (PDLSCs) are considered a promising cell source for dental tissue regeneration. Stromal cell-derived factor 1 [SDF-1, also known as chemokine (C-X-C motif) ligand 12] is regarded as a critical cytokine involved in stem/progenitor cell chemotaxis and homing during tissue regeneration. The present study described a previously unsuspected role for SDF-1 in the protection of PDLSCs against oxidative stress-induced apoptosis. In the present study, apoptosis was induced by exposure of PDLSCs to various concentrations of $\mathrm{H}_{2} \mathrm{O}_{2}$ for $12 \mathrm{~h}$, following which cell viability was assessed, and cleaved caspase- 3 and -9 expression levels were evaluated. To investigate the potential mechanism underlying this protection, the protein expression levels of total and phosphorylated extracellular signal-regulated kinase (ERK), a key protein of the mitogen-activated protein kinase (MAPK) signaling pathway, were examined. The results of the present study revealed that SDF-1 pretreatment increased cell viability following $\mathrm{H}_{2} \mathrm{O}_{2}$ administration, and downregulated protein expression levels of activated caspase-3 and -9. Furthermore, treatment with SDF-1 increased the phosphorylation of ERK. The protective effect of SDF-1 was partially inhibited by treatment with PD98059, a MAPK/ERK inhibitor, which decreased cell viability. The results of the present study suggested that SDF-1 treatment is a potential strategy to improve the survival of PDLSCs, which may be beneficial for dental tissue regeneration.
\end{abstract}

\section{Introduction}

Dental procedures, including tooth bleaching, laser radiation and exposure to dental materials, elevate levels of intracellular

Correspondence to: Dr Baiping Fu, Department of Prosthodontics, Affiliated Dental Hospital, Zhejiang University School of Medicine, 395 Yan'an Road, Hangzhou, Zhejiang 310000, P.R. China E-mail: bfu2326@163.com

Key words: periodontal ligament stem cells, stromal cell-derived factor 1, apoptosis, extracellular signal-regulated kinase, hydrogen peroxide reactive oxygen species (ROS), including hydrogen peroxide $\left(\mathrm{H}_{2} \mathrm{O}_{2}\right)$. ROS-induced oxidative stress has been documented to be closely associated with a series of deleterious effects causing degradation of connective tissue and modification to the periodontal structures (1). Therefore, further studies on the effect of oxidative stress on periodontal cells may further the understanding of the underlying mechanisms involved in periodontal apoptosis.

Periodontal ligament (PDL) stem cells (PDLSCs) have been reported to have restorative potential for the regeneration of tissues damaged by periodontal diseases (2). PDLSCs possess self-renewal and multipotent capabilities that regenerate cementum- and PDL-like tissues. As well as therapeutic application in dental tissue regeneration, PDLSCs have potential for the repair and regeneration of a variety of non-dental and non-oral tissues, including bone, cartilage, skeletal muscle, myocardium, spinal cord and peripheral nerves (3).

The chemokine stromal cell-derived factor-1 (SDF-1) is constitutively expressed and produced by PDLSCs. It serves an essential role in stem cell migration and homing by signaling via its cognate receptor, C-X-C chemokine receptor type 4 (CXCR4) (4). There are multiple shared vital functions between SDF-1 and CXCR4, as demonstrated by CXCR $4^{-/}$and SDF-1 ${ }^{-1-}$ animals, which exhibit similar phenotypic outcomes and suffer embryonic lethality at similar times during fetal development (5). As well as its role in development, the SDF-1/CXCR4 axis is important for cell survival. It has been demonstrated that SDF-1/CXCR4 signaling stimulates anti-apoptotic pathways in cultured trophoblasts via the mitogen-activated protein kinase (MAPK) signaling pathway (6). A recent study suggested that SDF-1 may regulate monocyte-macrophage differentiation and survival via differential engagement of CXCR4 (7). However, the effects and underlying mechanisms of SDF-1 treatment on survival of PDLSCs under oxidative stress remain largely unknown. The present study demonstrated the positive effects of SDF-1 pretreatment on PDLSC survival following exposure to $\mathrm{H}_{2} \mathrm{O}_{2}$, through the activation of extracellular signal-regulated kinase (ERK) signaling.

\section{Materials and methods}

Isolation of PDLSCs. PDLSCs were isolated and cultured as previously described (8), with slight modifications. 
Briefly, permanent teeth were collected from healthy young adults (age, 19-29 years) for orthodontic purposes at the Department of Orthodontics in Second Affiliated Hospital of Zhejiang University (Hangzhou, China). The study protocol was approved by the Ethics Committee of Zhejiang University and written informed consent was obtained from all donors. PDL tissues were scraped from the root surface and cut into fine pieces, followed by digestion for $2 \mathrm{~h}$ at $37^{\circ} \mathrm{C}$ in Dulbecco's modified Eagle's medium (DMEM)/F-12 (HyClone; Thermo Fisher Scientific, Inc., Waltham, MA, USA) containing $3 \mathrm{mg} / \mathrm{ml}$ collagenase type I (Sigma-Aldrich; Merck KGaA, Darmstadt, Germany) and $4 \mathrm{mg} / \mathrm{ml}$ dispase (Gibco; Thermo Fisher Scientific, Inc.). Following filtration through a cell strainer $(40-\mu \mathrm{m}$ pore size; BD Biosciences, Franklin Lakes, NJ, USA), the cells were maintained in DMEM/F-12 supplemented with $10 \%$ fetal bovine serum (Gibco; Thermo Fisher Scientific, Inc.), $2 \mathrm{mM}$ L-glutamine (HyClone; Thermo Fisher Scientific, Inc.), $100 \mathrm{U} / \mathrm{ml}$ penicillin and $100 \mathrm{mg} / \mathrm{ml}$ streptomycin (HyClone; Thermo Fisher Scientific, Inc.) and maintained at $37^{\circ} \mathrm{C}$ in a humidified atmosphere of $5 \% \mathrm{CO}_{2}$.

Cell viability assay. Cell viability was determined by the 3-(4,5-dimethylthiazol-2yl)-2,5-diphenyltetrazolium bromide (MTT) assay. At passage 3,2×104 PDLSCs were seeded into each well of 96-well plates and incubated for $24 \mathrm{~h}$, following which the medium was replaced with DMEM/F-12 containing 100-500 $\mu \mathrm{M} \mathrm{H}_{2} \mathrm{O}_{2}$ (Sigma-Aldrich; Merck KGaA) for $12 \mathrm{~h}$. Cell viability was determined by incubating with $5 \mathrm{mg} / \mathrm{ml}$ MTT solution at $37^{\circ} \mathrm{C}$ for $4 \mathrm{~h}$. Formazan crystals were subsequently dissolved with dimethyl sulfoxide, and the absorbance of each well was measured at a wavelength of $570 \mathrm{~nm}$ using a Multiskan $^{\mathrm{TM}}$ FC Microplate Photometer (Thermo Fisher Scientific, Inc.). All experiments were performed in quintuplicate for each dose. Cells cultured in DMEM/F-12 only served as a control.

The effect of SDF-1 on apoptosis was evaluated by adding recombinant human SDF-1a (PeproTech, Inc., Rocky Hill, NJ, USA) to PDLSCs at a final concentration of $50 \mathrm{ng} / \mathrm{ml}$ for $2 \mathrm{~h}$ prior to exposure to $100-500 \mu \mathrm{M} \mathrm{H}_{2} \mathrm{O}_{2}$ for a further $12 \mathrm{~h}$.

For ERK inhibition experiments, SDF-1-pretreated PDLSCs were treated with $100-500 \mu \mathrm{M} \mathrm{H}_{2} \mathrm{O}_{2}$ together with the ERK inhibitor PD98059 $(10 \mu \mathrm{M}$; Sigma-Aldrich; Merck $\mathrm{KGaA}$ ) for $12 \mathrm{~h}$, and the MTT assay was subsequently performed. Equivalent dilutions of PBS served as controls.

Knockdown of SDF-1 using small interfering (si)RNA. SDF-1 siRNA (5'-CGTCAAGCATCTCAAAAT-3') or scramble control siRNA were synthesized by Invitrogen; Thermo Fisher Scientific, Inc. PDLSCs $\left(1 \times 10^{5}\right)$ were seeded into a $35-\mathrm{mm}$ culture dish. A total of $24 \mathrm{~h}$ later, cells were transfected with 160 nM siRNA in Opti-MEM ${ }^{\circledR}$ medium (Thermo Fisher Scientific, Inc.) using Lipofectamine ${ }^{\circledR} 2000$ (Thermo Fisher Scientific, Inc.) according to the manufacturer's protocol. Reverse transcription-quantitative polymerase chain reaction (RT-qPCR) and western blot analysis were performed to determine the RNA interference efficacy $48 \mathrm{~h}$ after transfection. Also $48 \mathrm{~h}$ after transfection, SDF-1 downregulated PDLSCs were treated with $400 \mu \mathrm{M} \mathrm{H}_{2} \mathrm{O}_{2}$ for $12 \mathrm{~h}$, and total cellular proteins were extracted for western blot analysis.
Table I. Primary antibodies used in the present study.

\begin{tabular}{|c|c|c|c|c|}
\hline Antigen & Cat. no. & Raised in & Dilution & Supplier \\
\hline SDF-1 & ab155090 & Rabbit & $1: 10,000$ & Abcam \\
\hline Caspase-3 & ab2302 & Rabbit & $1: 200$ & Abcam \\
\hline Caspase-9 & ab63488 & Rabbit & $1: 1,000$ & Abcam \\
\hline ERK & 4695 & Rabbit & $1: 2,000$ & $\begin{array}{l}\text { Cell Signaling } \\
\text { Technology, Inc. }\end{array}$ \\
\hline p-ERK & 4370 & Rabbit & $1: 1,000$ & $\begin{array}{l}\text { Cell Signaling } \\
\text { Technology, Inc. }\end{array}$ \\
\hline GAPDH & ab181602 & Rabbit & $1: 10,000$ & Abcam \\
\hline
\end{tabular}

Abcam, Cambridge, UK; Cell Signaling Technology, Inc., Danvers, MA, USA. SDF-1, stromal cell-derived factor 1; ERK, extracellular signal-regulated kinase; $\mathrm{p}$, phosphorylated.

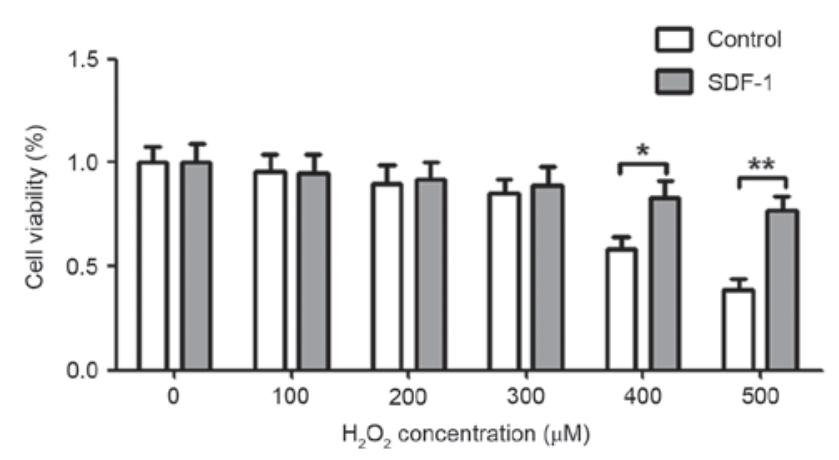

Figure 1. Protective effect of SDF-1 on $\mathrm{H}_{2} \mathrm{O}_{2}$-induced cytotoxicity in PDLSCs. PDLSCs were cultured for $12 \mathrm{~h}$ in presence of $0-500 \mu \mathrm{M} \mathrm{H}_{2} \mathrm{O}_{2}$ with or without pretreatment with $50 \mathrm{ng} / \mathrm{ml} \mathrm{SDF}-1$ for $2 \mathrm{~h}$. The viability of PDLSCs was measured by an MTT assay. Data are presented as the mean \pm standard deviation of three independent experiments. ${ }^{*} \mathrm{P}<0.05 ;{ }^{* *} \mathrm{P}<0.01$. SDF-1, stromal cell-derived factor 1; PDLSCs, periodontal ligament stem cells.

$R N A$ isolation and $R T-q P C R$. Total RNA was extracted from cells using TRIzol ${ }^{\circledR}$ reagent (Invitrogen; Thermo Fisher Scientific, Inc.) according to the manufacturer's protocol. Total RNA (2 $\mu \mathrm{g}$ ) from each sample was subjected to RT using the PrimeScript $^{\text {TM }}$ RT Reagent kit with Moloney Murine Leukemia Virus Reverse Transcriptase (Takara Biotechnology Co., Ltd., Dalian, China). The quantification of human SDF-1 and GAPDH was performed by qPCR on an Applied Biosystems 7500 Real-Time PCR system using a SYBR ${ }^{\circledR}$ Premix Ex Taq kit (Takara Biotechnology Co., Ltd.). PCR reactions were 40 cycles of denaturation at $94^{\circ} \mathrm{C}$ for $15 \mathrm{sec}, 30 \mathrm{sec}$ annealing and extension at $60^{\circ} \mathrm{C}$. Each value was normalized to $\beta$-actin. The relative expression level of the genes was calculated using $2-\Delta \Delta \mathrm{Ct}$ method as previously described $(9,10)$. Primer sequences were as follows: Forward, 5'-AGAATTCATGAA CGCCAAGG-3' and reverse, 5'-AGGATCCTCACATCTTGA ACC-3' for SDF-1; forward, 5'-AGGGCTGCTTTTAACTCT GGT-3' and reverse, 5'-CCCCACTTGATTTTGGAGGGA-3' for GAPDH.

Western blot analysis. PDLSCs were seeded into 6-well plates at a density of $5 \times 10^{5}$ cells/well and cultured for $24 \mathrm{~h}$. $\mathrm{H}_{2} \mathrm{O}_{2}$ was added at a final concentration of $400 \mu \mathrm{M}$ for $12 \mathrm{~h}$, 

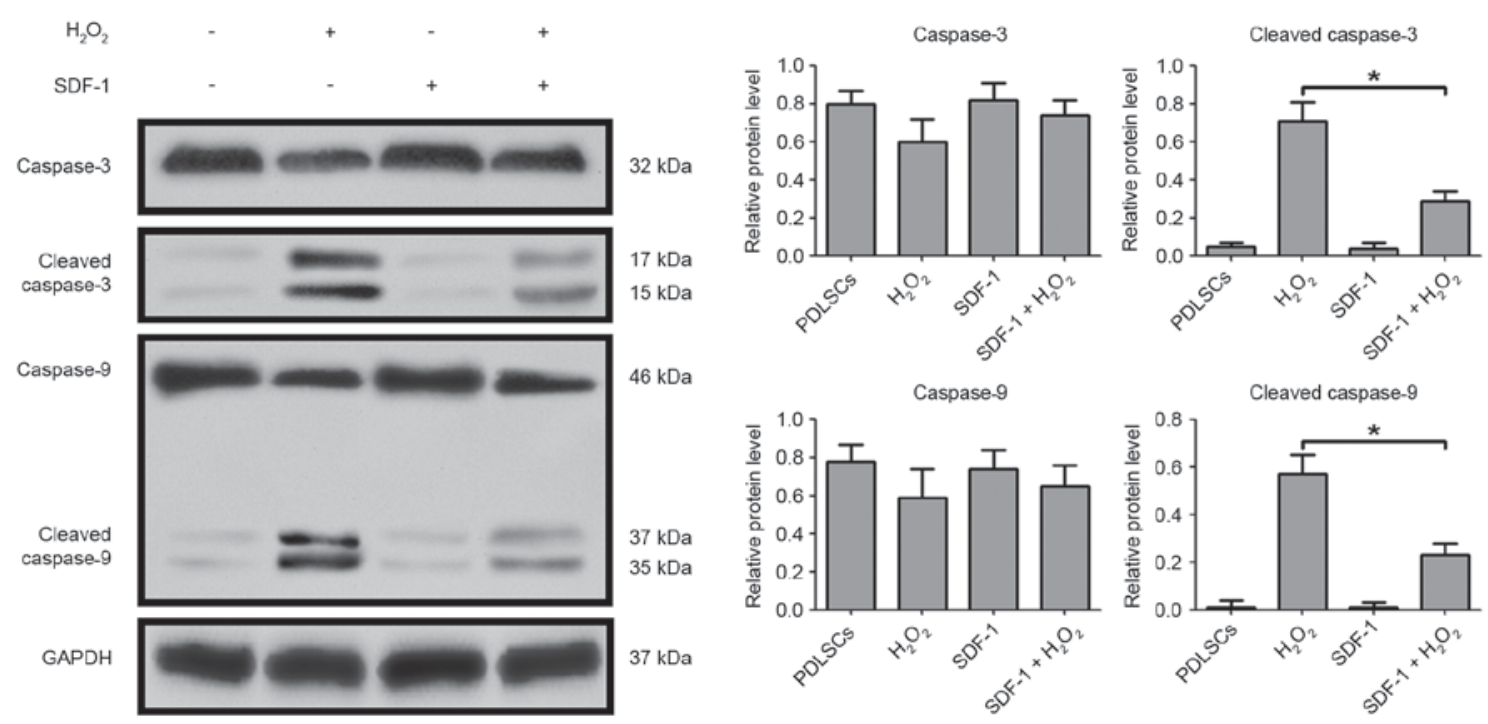

Figure 2. Western blot analysis of caspase-3 and -9 protein expression levels in total cell lysates. Periodontal ligament stem cells were untreated, treated with $400 \mu \mathrm{M} \mathrm{H}_{2} \mathrm{O}_{2}$ for $12 \mathrm{~h}$ or pretreated with $50 \mathrm{ng} / \mathrm{ml} \mathrm{SDF}-1$ for $2 \mathrm{~h}$ prior to treatment with $400 \mu \mathrm{M} \mathrm{H}_{2} \mathrm{O}_{2}$ for $12 \mathrm{~h}$. GAPDH served as a loading control. Data are presented as the mean \pm standard deviation of three independent experiments. ${ }^{*} \mathrm{P}<0.05$. SDF-1, stromal cell-derived factor 1.
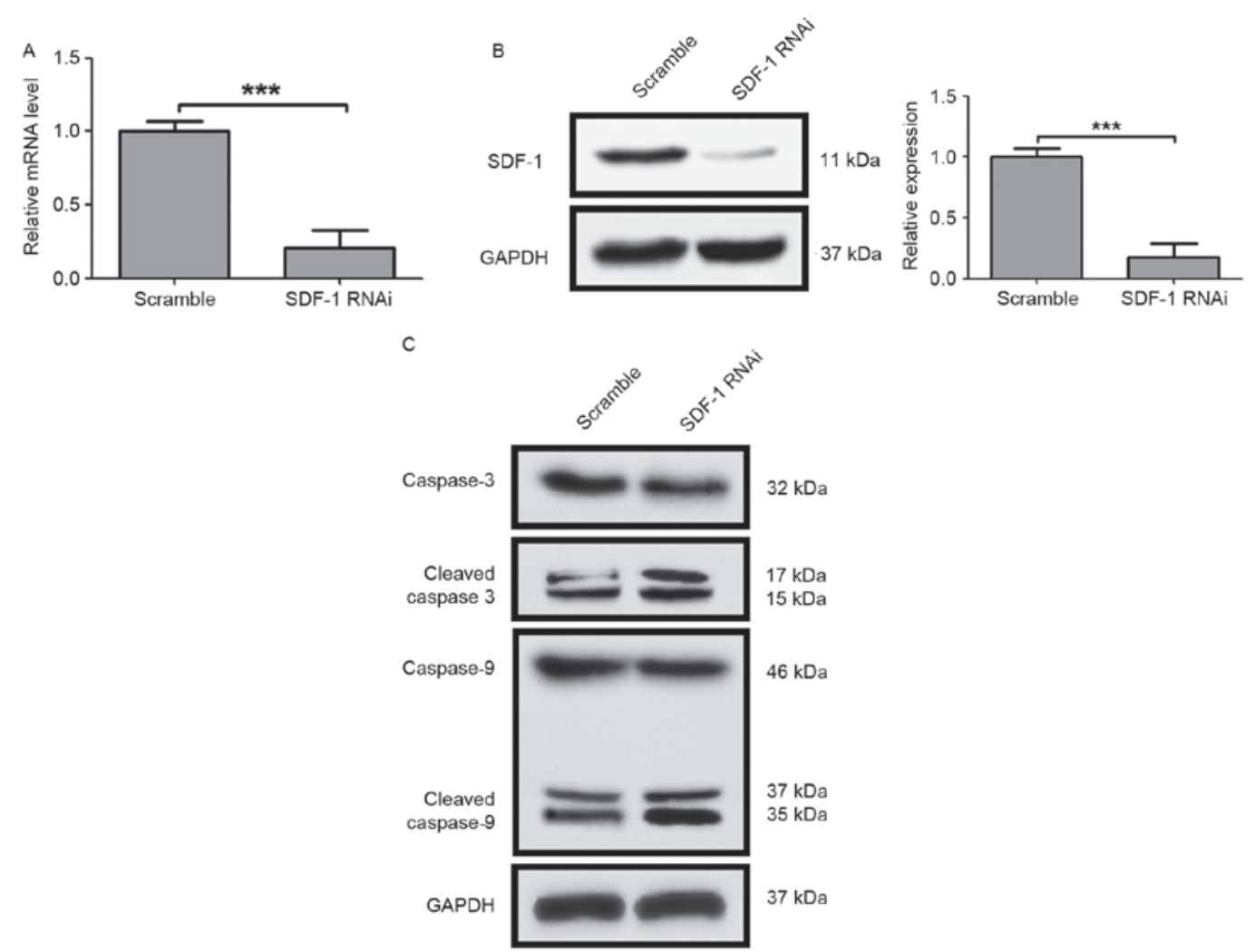

Figure 3. Downregulation of SDF-1 sensitizes PDLSCs to $\mathrm{H}_{2} \mathrm{O}_{2}$-induced caspase activation. A total of $48 \mathrm{~h}$ after transfection with SDF-1 or scramble control siRNA, SDF-1 expression was decreased at the (A) mRNA and (B) protein levels in PDLSCs. GAPDH served as an internal control. (C) SDF-1 knockdown increased the activation level of caspases in PDLSCs. PDLSCs were treated with $400 \mu \mathrm{M} \mathrm{H}_{2} \mathrm{O}_{2}$ for $12 \mathrm{~h}, 2$ days following transfection with SDF-1 or scramble control siRNA, and protein expression levels of pro- and cleaved forms of caspase- 3 and -9 were determined by western blot analysis. Data are presented as the mean \pm standard deviation of three independent experiments. ${ }^{* * *} \mathrm{P}<0.001$. SDF-1, stromal cell-derived factor 1; PDLSCs, periodontal ligament stem cells; siRNA, small interfering RNA.

following which cells were lysed and protein concentration was determined using a Bicinchoninic Acid Protein assay kit (Pierce; Thermo Fisher Scientific, Inc.). Total proteins (40 $\mu \mathrm{g}$ per lane) were loaded onto $12 \%$ SDS-PAGE gels, separated by electrophoresis and transferred onto polyvinylidene difluoride membranes. Membranes were blocked with 5\% skimmed milk in 1XTris Buffered Saline Tween-20 and probed with the primary antibodies listed in Table I for 

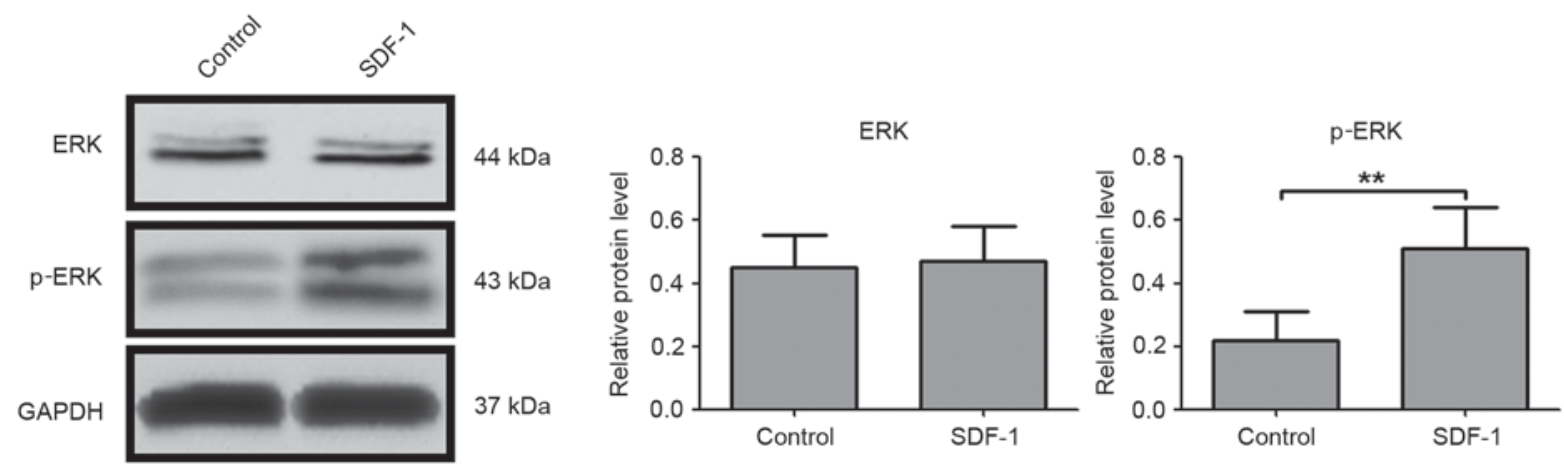

Figure 4. SDF-1 regulates the activation of the ERK signaling pathway. Western blot analysis of ERK and p-ERK proteins in periodontal ligament stem cells treated with $50 \mathrm{ng} / \mathrm{ml} \mathrm{SDF}-1$ for $2 \mathrm{~h}$. GAPDH served as a loading control. Data are presented as the mean \pm standard deviation of three independent experiments. ${ }^{* *} \mathrm{P}<0.01$. SDF-1, stromal cell-derived factor 1; ERK, extracellular signal-regulated kinase; $\mathrm{p}$, phosphorylated.

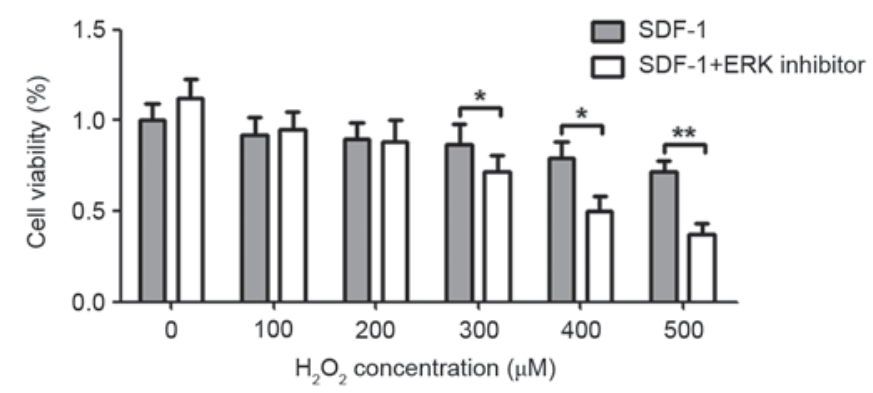

Figure 5. Inhibition of the ERK signaling pathway suppresses the increased survival in SDF-1-pretreated cells under oxidative stress. PDLSCs were pretreated with $50 \mathrm{ng} / \mathrm{ml} \mathrm{SDF}-1$ for $2 \mathrm{~h}$ prior to culture with $0-500 \mu \mathrm{M}$ $\mathrm{H}_{2} \mathrm{O}_{2}$ for a further $12 \mathrm{~h}$. To block ERK signaling, SDF-1 pretreated cells were cultured with 0-500 $\mu \mathrm{M} \mathrm{H}_{2} \mathrm{O}_{2}$ and $10 \mu \mathrm{M} \mathrm{ERK}$ inhibitor PD98059 for $12 \mathrm{~h}$. The viability of PDLSCs was measured using an MTT assay. Data are presented as the mean \pm standard deviation of three independent experiments. ${ }^{~} \mathrm{P}<0.05 ;{ }^{* *} \mathrm{P}<0.01$. ERK, extracellular signal-regulated kinase; SDF-1, stromal cell-derived factor 1; PDLSCs, periodontal ligament stem cells.

overnight at $4^{\circ} \mathrm{C}$, followed by a horseradish peroxidase-conjugated secondary antibody (65-6120; 1:20,000; Invitrogen; Thermo Fisher Scientific, Inc.) at room temperature for $2 \mathrm{~h}$. The protein bands were detected by Pierce ${ }^{\mathrm{TM}}$ Western Blot Signal Enhancer (Thermo Fisher Scientific, Inc.), and densitometry was performed using Image $\mathrm{J}$ software version $1.50 \mathrm{~b}$ (National Institutes of Health, Bethesda, MD, USA). Experiments were repeated at least three times.

Statistical analysis. Data are expressed as the mean \pm standard deviation. Statistical analysis was performed using SPSS software version 16.0 (SPSS, Inc., Chicago, IL, USA). Statistical significance was evaluated using two-tailed Student's t-test or one-way analysis of variance. Multiple comparisons between the groups was performed using the $\mathrm{S}-\mathrm{N}-\mathrm{K}$ method. $\mathrm{P}<0.05$ was considered to indicate a statistically significant difference.

\section{Results}

SDF-1 inhibits $\mathrm{H}_{2} \mathrm{O}_{2}$-induced cytotoxicity. To evaluate $\mathrm{H}_{2} \mathrm{O}_{2}$-induced cytotoxicity, PDLSCs were treated with 0,100 , $200,300,400$ or $500 \mu \mathrm{M} \mathrm{H}_{2} \mathrm{O}_{2}$ for $12 \mathrm{~h}$ and the cell viability was determined by MTT assay. $\mathrm{H}_{2} \mathrm{O}_{2}$ treatment reduced cell viability in a dose-dependent manner (Fig. 1). Following treatment with $400 \mu \mathrm{M} \mathrm{H}_{2} \mathrm{O}_{2} 57.4 \pm 5.9 \%$ of cells survived; this concentration was therefore used for subsequent experiments. The viability of the SDF-1 pretreated cells was similar to untreated control cells and $\mathrm{H}_{2} \mathrm{O}_{2}$-treated cells when exposed to $\mathrm{H}_{2} \mathrm{O}_{2}$ concentrations $\leq 300 \mu \mathrm{M}$. However, cell death induced by 400 and $500 \mu \mathrm{M} \mathrm{H}_{2} \mathrm{O}_{2}$ was significantly ameliorated by SDF-1 pretreatment.

SDF-1 pretreatment decreases caspase activity. Activation of the caspase cascade is the most important component of programmed cell death. To investigate whether the protective effects of SDF-1 are associated with altered caspase activation, pro- and cleaved caspases were detected by western blot analysis in PDLSCs cultured with $400 \mu \mathrm{M} \mathrm{H}_{2} \mathrm{O}_{2}$ for $12 \mathrm{~h}$ with or without SDF-1 pretreatment. The protein expression levels of cleaved caspase-3 and -9 significantly increased following treatment with $\mathrm{H} 2 \mathrm{O} 2$ (Fig. 2). Pretreatment with $50 \mathrm{ng} / \mathrm{ml}$ SDF-1 attenuated this increase, but did not alter the protein expression levels of pro-caspase-3 and -9 (Fig. 2). These data indicated that the protective effect of SDF-1 may be at least partially due to the suppression of caspase activation.

Depletion of SDF-1 sensitizes PDLSCs to $\mathrm{H}_{2} \mathrm{O}_{2}$-induced apoptosis. To further confirm the role of SDF-1 in $\mathrm{H}_{2} \mathrm{O}_{2}$-induced apoptosis, SDF-1 or scramble control siRNA was transfected into PDLSCs. After 2 days, mRNA and protein expression levels of SDF-1 in the transfected PDLSCs were measured. Following silencing, the mRNA (Fig. 3A) and protein (Fig. 3B) expression levels of SDF-1 were reduced by $89 \pm 12$ and $92 \pm 11 \%$, respectively, compared with scramble control. Western blot analysis revealed that, compared to scramble control cells, SDF-1 knockdown cells had greater protein expression levels of activated caspase- 3 and -9 following $\mathrm{H}_{2} \mathrm{O}_{2}$ treatment (Fig. 3C). These results suggested a specific contribution of SDF-1 in protecting PDLSCs from $\mathrm{H}_{2} \mathrm{O}_{2}$-induced apoptosis.

SDF-1 induces the activation of the ERK signaling pathway. The signaling pathway responsible for SDF-1 protection against apoptosis was subsequently investigated. As activation of the ERK signaling pathway has been demonstrated to inhibit apoptosis in response to a wide range of stimuli, including oxidative stress (11), it was hypothesized that ERK may be 
involved in SDF-1-mediated protection against $\mathrm{H}_{2} \mathrm{O}_{2}$-induced cytotoxicity. To test this hypothesis, protein expression levels of the activated and inactivated forms of ERK were examined in PDLSCs treated with $50 \mathrm{ng} / \mathrm{ml} \mathrm{SDF}-1$ for $2 \mathrm{~h}$ (Fig. 4). Densitometry analysis revealed that SDF-1 treatment activates ERK via an increase in the protein expression levels of phosphorylated ERK.

SDF-1-mediated protection against $\mathrm{H}_{2} \mathrm{O}_{2}$-induced cytotoxicity of PDLSCs is suppressed by inhibition of ERK. To further investigate whether the ERK signaling pathway is critical for the anti-apoptotic effect of SDF-1 on PDLSCs, the effect of PD98059, an ERK-specific inhibitor, on SDF-1-induced cell survival was assessed. Addition of $10 \mu \mathrm{M}$ PD98059 to PDLSCs significantly inhibited the protective effect of SDF-1 pretreatment against $\mathrm{H}_{2} \mathrm{O}_{2}$ concentrations $\geq 300 \mu \mathrm{M}$ (Fig. 5). These results supported the role of the ERK signaling pathway in the increased survival mediated by SDF-1 pretreatment. Comparisons between normal PDLSCs and SDF-1 pretreatment after ERK inhibition were not performed as the major focus of the present study was to validate the involvement of ERK pathway in SDF-1-mediated cytoprotection.

\section{Discussion}

The SDF-1/CXCR4 axis has been reported to be associated with multiple biological processes, including cell survival, proliferation, adhesion and growth factor secretion (12). SDF-1 is vital in myocardiocytes (13), myeloid cells, neurons (14), leukocytes (15) and muscle precursors (16), and is particularly associated with the promotion of cell survival. The findings of the present study indicated that SDF-1 pretreatment may improve the efficacy of PDLSC-associated tissue regeneration.

Recently, PDLSCs have been investigated for their potential application in regenerative medicine, due to their availability and multipotency (17). Various physiological microenvironments, including mechanical stress and hypoxia, serve a vital role in PDLSC-associated dental tissue regeneration (18). As cell survival is necessary for dental tissue regeneration by PDLSCs, numerous strategies have been investigated to improve the resistance of stem cells to lethal stimuli. Upregulation of pro-survival molecules, including protein kinase B, Pim-1, B-cell lymphoma 2 (Bcl-2) and stem cell factor, protect against apoptosis in stem cells (19-21). In addition, pharmacological pretreatment with growth factors or cytokines may improve the regenerative capability of stem cells (22).

The present study demonstrated that SDF-1 pretreatment increased PDLSC viability in response to oxidative stress, consistent with recent findings in mesenchymal stem cells (MSCs) (23). It was also reported that overexpression of SDF-1 in MSCs significantly increased cell survival after transplantation into rats with acute myocardial infarction (24), indicating a beneficial role of SDF-1 in stem cell-based therapy. In addition, the present study revealed that exposure to $\mathrm{H}_{2} \mathrm{O}_{2}$ led to an increase in the protein expression levels of cleaved caspase- 3 and -9 , which were decreased by SDF-1 pretreatment. Increased levels of activated caspases were additionally detected when SDF-1 was silenced in PDLSCs, which provided further evidence supporting the protective role of SDF-1.
There is evidence that the cytoprotective effects of SDF-1 may be conferred via the activation of intracellular pro-survival kinases (25). Although the specific signaling mechanism remains unclear, it is hypothesized to involve the MAPK signaling pathway and exert protection by deactivating Bcl-2 family pro-apoptotic proteins (26). The present study demonstrated that SDF-1 pretreatment activated ERK. Using a specific inhibitor of ERK, the contribution of this kinase to the survival of $\mathrm{H}_{2} \mathrm{O}_{2}$-treated PDLSCs was analyzed. Inhibition of ERK significantly decreased the survival of SDF-1 pretreated cells in response to oxidative stress. This finding supported and extended the hypothesis of Xia et al (27), which stated that the dynamic balance between ERK and its activated form is important in determining cell survival or apoptosis.

In conclusion, the results of the present study suggested that exogenous SDF-1 exerts effective protection against $\mathrm{H}_{2} \mathrm{O}_{2}$-induced apoptosis. This protection, in primary human PDLSCs, occurs via the activation of the ERK signaling pathway. Thus, SDF-1 could be a novel regime for improving PDLSCs-based cellular therapy.

\section{Acknowledgements}

The present study was supported by the Administration of Traditional Chinese Medicine of Zhejiang Province (grant no. 2014ZA069) and the Department of Education of Zhejiang Province (grant no. Y201534720).

\section{References}

1. Waddington RJ, Moseley R and Embery G: Reactive oxygen species: A potential role in the pathogenesis of periodontal diseases. Oral Dis 6: 138-151, 2000.

2. Zhang J, An Y, Gao LN, Zhang YJ, Jin Y and Chen FM: The effect of aging on the pluripotential capacity and regenerative potential of human periodontal ligament stem cells. Biomaterials 33: 6974-6986, 2012.

3. Xiao L and Nasu M: From regenerative dentistry to regenerative medicine: Progress, challenges, and potential applications of oral stem cells. Stem Cells Cloning 7: 89-99, 2014.

4. Peled A, Petit I, Kollet O, Magid M, Ponomaryov T, Byk T, Nagler A, Ben-Hur H, Many A, Shultz L, et al: Dependence of human stem cell engraftment and repopulation of NOD/SCID mice on CXCR4. Science 283: 845-848, 1999.

5. Ma Q, Jones D, Borghesani PR, Segal RA, Nagasawa T, Kishimoto T, Bronson RT and Springer TA: Impaired B-lymphopoiesis, myelopoiesis, and derailed cerebellar neuron migration in CXCR4- and SDF-1-deficient mice. Proc Natl Acad Sci USA 95: 9448-9453, 1998.

6. Jaleel MA, Tsai AC, Sarkar S, Freedman PV and Rubin LP: Stromal cell-derived factor-1 (SDF-1) signalling regulates human placental trophoblast cell survival. Mol Hum Reprod 10: 901-909, 2004

7. Chatterjee M, von Ungern-Sternberg SNI, Seizer P, Schlegel F, Büttcher M, Sindhu NA, Müller S, Mack A and Gawaz M: Platelet-derived CXCL12 regulates monocyte function, survival, differentiation into macrophages and foam cells through differential involvement of CXCR4-CXCR7. Cell Death Dis 6: e1989, 2015.

8. Seo BM, Miura M, Gronthos S, Bartold PM, Batouli S, Brahim J, Young M, Robey PG, Wang CY and Shi S: Investigation of multipotent postnatal stem cells from human periodontal ligament. Lancet 364: 149-155, 2004.

9. Livak KJ and Schmittgen TD: Analysis of relative gene expression data using real-time quantitative PCR and the 2(-Delta Delta C(T)) method. Methods 25: 402-408, 2001.

10. Bi H, Ming L, Cheng R, Luo H, Zhang Y and Jin Y: Liver extracellular matrix promotes BM-MSCs hepatic differentiation and reversal of liver fibrosis through activation of integrin pathway. J Tissue Eng Regen Med: Jul 19, 2016 (Epub ahead of print). 
11. Wang X, Martindale JL, Liu Y and Holbrook NJ: The cellular response to oxidative stress: Influences of mitogen-activated protein kinase signalling pathways on cell survival. Biochem J 333: 291-300, 1998.

12. Puchert M and Engele J: The peculiarities of the SDF-1/CXCL12 system: In some cells, CXCR4 and CXCR7 sing solos, in others, they sing duets. Cell Tissue Res 355: 239-253, 2014.

13. Malik A, Bromage DI, He Z, Candilio L, Hamarneh A, Taferner S, Davidson SM and Yellon DM: Exogenous SDF-1 $\alpha$ protects human myocardium from hypoxia-reoxygenation injury via CXCR4 Cardiovasc Drugs Ther 29: 589-592, 2015.

14. Heskamp A, Leibinger M, Andreadaki A, Gobrecht P, Diekmann H and Fischer D: CXCL12/SDF-1 facilitates optic nerve regeneration. Neurobiol Dis 55: 76-86, 2013.

15. Gawaz M: Leukocyte adhesion and activation in atherothrombosis. Blood 122: SCI-52, 2013.

16. Masyuk M, Abduelmula A, Morosan-Puopolo G, Ödemis V, Rehimi R, Khalida N, YusufF, Engele J, Tamamura H, Theiss C and Brand-Saberi B: Retrograde migration of pectoral girdle muscle precursors depends on CXCR4/SDF-1 signaling. Histochem Cell Biol 142: 473-488, 2014

17. $\mathrm{Bi} \mathrm{H}$ and Jin $\mathrm{Y}$ : Current progress of skin tissue engineering: Seed cells, bioscaffolds, and construction strategies. Burns Trauma 1: 63-72, 2013.

18. Liu N, Shi S, Deng M, Tang L, Zhang G, Liu N, Ding B, Liu W, Liu Y, Shi $\mathrm{H}$, et al: High levels of $\beta$-Catenin signaling reduce osteogenic differentiation of stem cells in inflammatory microenvironments through inhibition of the noncanonical Wnt pathway. J Bone Miner Res 26: 2082-2095, 2011.

19. Fischer KM, Cottage CT, Wu W, Din S, Gude NA, Avitabile D, Quijada P, Collins BL, Fransioli J and Sussman MA: Enhancement of myocardial regeneration through genetic engineering of cardiac progenitor cells expressing Pim-1 kinase. Circulation 120 2077-2087, 2009.
20. Li W, Ma N, Ong LL, Nesselmann C, Klopsch C, Ladilov Y, Furlani D, Piechaczek C, Moebius JM, Lützow K, et al: Bcl-2 engineered MSCs inhibited apoptosis and improved heart function. Stem Cells 25: 2118-2127, 2007.

21. Fazel SS, Angoulvant D, Butany J, Weisel RD and Li RK: Mesenchymal stem cells engineered to overexpress stem cell factor improve cardiac function but have malignant potential. J Thorac Cardiovasc Surg 136: 1388-1389, 2008.

22. Haider HKh and Ashraf M: Strategies to promote donor cell survival: Combining preconditioning approach with stem cell transplantation. J Mol Cell Cardiol 45: 554-566, 2008.

23. Liu X, Duan B, Cheng Z, Jia X, Mao L, Fu H, Che Y, Ou L, Liu L and Kong D: SDF-1/CXCR4 axis modulates bone marrow mesenchymal stem cell apoptosis, migration and cytokine secretion. Protein Cell 2: 845-854, 2011.

24. Zhang M, Mal N, Kiedrowski M, Chacko M, Askari AT, Popovic ZB, Koc ON and Penn MS: SDF-1 expression by mesenchymal stem cells results in trophic support of cardiac myocytes after myocardial infarction. FASEB J 21: 3197-3207, 2007.

25. Davidson SM, Selvaraj P, He D, Boi-Doku C, Yellon RL, Vicencio JM and Yellon DM: Remote ischaemic preconditioning involves signalling through the SDF-1 $\alpha / C X C R 4$ signalling axis. Basic Res Cardiol 108: 377, 2013.

26. Suzuki Y, Rahman M and Mitsuya H: Diverse transcriptional response of CD4+ T cells to stromal cell-derived factor SDF-1: Cell survival promotion and priming effects of SDF-1 on CD4+ T cells. J Immunol 167: 3064-3073, 2001.

27. Xia Z, Dickens M, Raingeaud J, Davis RJ and Greenberg ME: Opposing effects of ERK and JNK-p38 MAP kinases on apoptosis. Science 270: 1326-1331, 1995. 